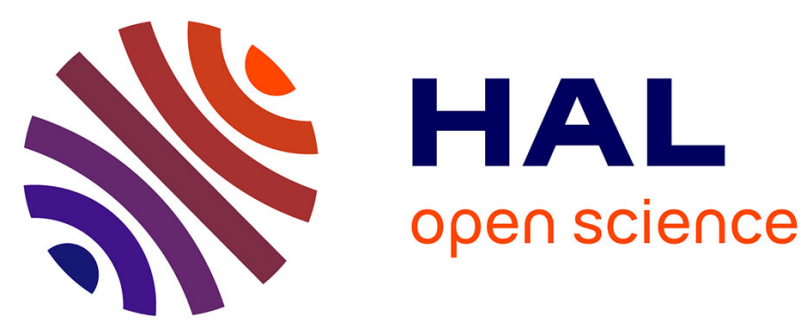

\title{
Enhancement of fermentative hydrogen production by Thermotoga maritima through hyperthermophilic anaerobic co-digestion of fruit-vegetable and fish wastes
}

Rafika Saidi, Pierre-Pol Liebgott, Moktar Hamdi, Richard Auria, Hassib Bouallagui

\section{To cite this version:}

Rafika Saidi, Pierre-Pol Liebgott, Moktar Hamdi, Richard Auria, Hassib Bouallagui. Enhancement of fermentative hydrogen production by Thermotoga maritima through hyperthermophilic anaerobic co-digestion of fruit-vegetable and fish wastes. International Journal of Hydrogen Energy, 2018, 43 (52), pp.23168-23177. 10.1016/j.ijhydene.2018.10.208 . hal-01976197

\section{HAL Id: hal-01976197 \\ https://hal.science/hal-01976197}

Submitted on 8 Feb 2019

HAL is a multi-disciplinary open access archive for the deposit and dissemination of scientific research documents, whether they are published or not. The documents may come from teaching and research institutions in France or abroad, or from public or private research centers.
L'archive ouverte pluridisciplinaire HAL, est destinée au dépôt et à la diffusion de documents scientifiques de niveau recherche, publiés ou non, émanant des établissements d'enseignement et de recherche français ou étrangers, des laboratoires publics ou privés. 


\title{
Enhancement of fermentative hydrogen production by Thermotoga maritima through hyperthermophilic anaerobic co-digestion of fruit-vegetable and fish wastes
}

\author{
Rafika Saidi ${ }^{a}$, Pierre Pol Liebgott ${ }^{b}$, Moktar Hamdi $^{a}$, Richard Auria ${ }^{b}$, \\ Hassib Bouallagui ${ }^{a, *}$ \\ ${ }^{a}$ Université de Carthage, Laboratoire d'Ecologie et de Technologie Microbienne LETMi, INSAT, B.P. 676, 1080 Tunis, \\ Tunisia \\ ${ }^{\mathrm{b}}$ Aix Marseille Université, CNRS, Université de Toulon, IRD, MIO UM 110, 13288 Marseille, France
}

\section{A R T I C L E I N F O}

Article history:

Received 17 July 2018

Received in revised form

4 October 2018

Accepted 25 October 2018

Available online $\mathrm{xxx}$

Keywords:

Biohydrogen

T. maritima

Fruit and vegetable wastes

Fish wastes

Seawater

Dark fermentation

\begin{abstract}
A B S T R A C T
In this work, different proportions of model fruit and vegetable wastes (MFVW) and acid hydrolyzed fish wastes (AHFW) were used for hydrogen production in a minimum culture medium based on seawater. Experiments were performed in $\mathrm{pH}$-controlled Stirred Tank Reactor (STR) with or without the addition of nitrogen and sulfur sources. The total $\mathrm{H}_{2}$ production and the maximum hydrogen productivity of $\mathrm{T}$. maritima in the culture medium, containing MFVW and AHFW (45 mmol L $\mathrm{L}^{-1}$ carbohydrates) at a $\mathrm{C} / \mathrm{N}$ ratio of 12 , were $132 \mathrm{mmol} \mathrm{L}^{-1}$ and $15 \mathrm{mmol} \mathrm{h}^{-1} \mathrm{~L}^{-1}$, respectively. However, tripling the concentration of carbohydrates to reach a $\mathrm{C} / \mathrm{N}$ ratio of 22 , has increased two times the maximum $\mathrm{H}_{2}$ productivity $\left(28 \mathrm{mmol} \mathrm{h}^{-1} \mathrm{~L}^{-1}\right.$ ) due to the improvement in nutrient balance. The cumulative $\mathrm{H}_{2}$ production was $285 \mathrm{mmol} \mathrm{L}^{-1}$, yielding a potential energy generation of $0.1210^{3} \mathrm{MJ}^{\mathrm{ton}} \mathrm{ton}^{-1}$ wastes, which could be an interesting alternative for energy recovery.
\end{abstract}

(C) 2018 Hydrogen Energy Publications LLC. Published by Elsevier Ltd. All rights reserved.

\section{Introduction}

Today, $80 \%$ of global energy demands depend on fossil fuels which have led to the greenhouse gas emissions and environmental pollution [1]. However, renewable energy sources have an increased interest in recent years because they have the aptitude to reduce the dependence on fossil fuels and their environmental impact [1]. Hydrogen seems to be the most attractive clean future energy vector for electricity generation in fuel cells, as well as an interesting gaseous biofuel for the transportation sector [2]. It is widely generated directly or indirectly from fossil fuel resources, but it can also be

Abbreviations: AHFW, acid hydrolyzed fish wastes; COD, chemical oxygen demand ( $\mathrm{g} \mathrm{L}^{-1}$ ); FVW, fruit and vegetable wastes; FW, fish wastes; MFVW, model fruit and vegetable wastes; STR, stirred tank reactor; TS, total solids (\%/wet basis); VS, volatile solids (\%/TS).

* Corresponding author.

E-mail address: hassibbouallagui@yahoo.fr (H. Bouallagui). 
produced sustainably from renewable resources (sun, wind, hydropower, and biomass) [3].

$\mathrm{H}_{2}$ production by dark fermentation is usually preferred due to its low energy requirements, a low operating cost, a higher rate of $\mathrm{H}_{2}$ and the use of a wide range of organic wastes [4-6]. The highest fermentative $\mathrm{H}_{2}$ yields were obtained with hyperthermophilic microorganisms to avoid the risk of contamination by other $\mathrm{H}_{2}$-consuming microorganisms, to promote the reaction kinetics and to decrease the hydrogen solubility [7-10]. Thermotoga maritima, which belongs to the order Thermotogales has been considered an excellent candidate for $\mathrm{H}_{2}$ production from various simple and complex carbohydrates [11-13]. It produces thermostable enzymes involved in the hydrolysis of complex polysaccharides into simple sugars [14]. Many studies showed a strong correlation between $\mathrm{T}$. maritima cell growth and its ability to produce $\mathrm{H}_{2}$. It showed the highest $\mathrm{H}_{2}$ yield which is close to the Thauer limit (4 mol $\mathrm{H}_{2}$ per mol glucose) with acetate as the main end product [15].

The fermentative $\mathrm{H}_{2}$ production process needs a large amount of water. Therefore, using seawater instead of freshwater has many advantages. It is an alternative solution for scaling-up the fermentation process as reported by other studies [16-18]. It reduces the freshwater consumption and avoids the risk of contamination by non-halophilic microorganisms. In addition, seawater contains mineral compounds and salts that will be potentially used for bacterial growth. The average composition of seawater depends on the geographical areas. It contains $\left(\mathrm{g} \mathrm{L}^{-1}\right) \mathrm{NaCl}$ (27.133), $\mathrm{MgCl}_{2}$ (2.504), $\mathrm{MgSO}_{4}$ (3.382), $\mathrm{CaCl}_{2}$ (1.167), $\mathrm{KCl}$ (0.742), $\mathrm{NaHCO}_{3}$ (0.207), $\mathrm{NaBr}(0.085)$ and total salts (35.220) [18]. Therefore, Saidi et al. [19] reported that using a simplified culture medium composed of fruit and vegetable wastes (FVW) and natural seawater provided several nutrients which have replaced certain components necessary for $\mathrm{T}$. maritima growth. The maximum hydrogen productivity and the hydrogen yield were $12.4 \mathrm{mmol} \mathrm{h}^{-1} \mathrm{~L}^{-1}$ and $3.89 \mathrm{~mol} \mathrm{H}_{2} \mathrm{~mol}^{-1}$ hexose, respectively [19].

Producing biohydrogen from biomass, rich in carbohydrates such as FVW and without chemical compounds addition, is an interesting cost-effective process. However, FVW are characterized by a low nitrogen content which limits the dark fermentation efficiency [20]. Bouallagui et al. [21] showed that the supply of co-substrates with high nitrogen content is a solution to adjust FVW nutrient balance for biogas production. Among these co-substrates, fish wastes (FW) were considered the highly biodegradable meat. In Tunisia, sardines are the most widely consumed blue fish species due to their availability and low cost [22]. However, they are susceptible to rapid deterioration [23]. Consequently, using the co-digestion process of FVW with FW is interesting technology for biohydrogen production.

Kim et al. [24] obtained $\mathrm{H}_{2}$ yield of $2.11 \mathrm{~mol} \mathrm{H}_{2} \mathrm{~mol}^{-1}$ hexose by using food wastes to sewage sludge ratio equal to $10: 1$ (w/w on a COD basis). This production was $13 \%$ higher than that obtained by using food wastes alone [24]. The highest $\mathrm{H}_{2}$ production rate $\left(3.27 \mathrm{LH}_{2} \mathrm{~L}^{-1} \mathrm{~d}^{-1}\right)$ obtained by Tenca et al. [25] was achieved by using a mixture of FVW and swine manure with a ratio of $35 / 65$. Also, Gomez-Romero et al. [26] were combined fruit and FVW with crude cheese whey at a $\mathrm{C} / \mathrm{N}$ ratio of 21 to optimize $\mathrm{H}_{2}$ production. The maximum volumetric $\mathrm{H}_{2}$ production rate, and $\mathrm{H}_{2}$ yield were $10.56 \mathrm{mmol}$ $\mathrm{H}_{2} \mathrm{~h}^{-1} \mathrm{~L}^{-1}$, and $449.84 \mathrm{~mL} \mathrm{H}_{2} \mathrm{~g} \mathrm{COD}^{-1}$, respectively.

In this study, it is the first time where the hyperthermophilic bacterium T. maritima was used for biohydrogen production from FVW and FW co-fermentation. In fact, FW are characterized by a high content of nitrogen which is important for a better $\mathrm{C} / \mathrm{N}$ ratio establishment. In addition, marine hyperthermophilic microorganisms are able to grow better on culture medium prepared with seawater rather than freshwater. Using hyperthermophilic co-digestion has several benefits. It increases the hydrolysis rate of the polymeric feedstock because hyperthermophilic hydrolytic enzymes have a highly stable activity with a better affinity to their substrates $[27,28]$. Therefore, the use of hyperthermophilic conditions has a positive effect on the solubilization of the cosubstrate mixture which is better for higher and faster production of hydrogen. The potential of fish wastes (Sardina pilchardus) as an alternative source of nitrogen and sulfur was evaluated to avoid the addition of chemical products $\left(\mathrm{NH}_{4} \mathrm{Cl}\right.$ and cysteine $\mathrm{HCl}$ ). Different $\mathrm{C} / \mathrm{N}$ ratios, obtained by mixing different proportions of MFVW and AHFW, were used to evaluate the potential of hydrogen production and the metabolic pathway of T. maritima.

\section{Material and methods}

\section{Substrates composition and preparation}

In order to obtain reproducible conditions, model fruit and vegetable wastes (MFVW) were used with a specific composition. The main constituents of MFVW (g/kg) were: plums (207), peaches (207), apples (207), carrots (138), potatoes (130) and tomatoes (110). MFVW were crushed with an electric blender into small pieces measuring less than $2 \mathrm{~mm}$ in length and width. They were filtered, fully mixed and directly frozen at $-20{ }^{\circ} \mathrm{C}$ until further use.

Sardines (Sardina pilchardus) were obtained from the Bir Kassa wholesale market located in Tunis (Tunisia). The whole fish (heads, bones, skin, and viscera) was grounded with an electric blender and homogenized. Viscera Fish (stomach, pancreas, and intestine) contain endogenous enzymes that can contribute to the hydrolysis of proteins. However, sardine muscles are composed of several groups of proteins (sarcoplasmic, myofibrillar, and stroma proteins) that are difficult to be used for bacteria growth [29]. Therefore, a pretreatment of sardines is required to obtain a suitable liquid easily used as a nitrogen source.

Acid-hydrolysis of sardines was combined with the water extraction as described by Gao et al. [30]. The minced sardines were mixed with water of equal weight. They were pretreated at $121{ }^{\circ} \mathrm{C}$ for $20 \mathrm{~min}$ and centrifuged at $3000 \mathrm{~g}$ for $20 \mathrm{~min}$ to separate the residue and the supernatant. The obtained residue was diluted with water to a ratio of $1 / 10$ and the $\mathrm{pH}$ was set at around 2 by the addition of $6 \mathrm{M} \mathrm{HCl}$. The acidified sample was pretreated again at $121^{\circ} \mathrm{C}$ and centrifuged at $3000 \mathrm{~g}$ for $20 \mathrm{~min}$. The first and the second supernatants were mixed and stored at $-20{ }^{\circ} \mathrm{C}$ for later use. The degree of organic matter acidification, coming from pretreated sardines, was calculated: 
Acidification yield $(\%)=\left(\left(\mathrm{TSS}_{\mathrm{i}}-\mathrm{TSS}_{\mathrm{f}}\right) / \mathrm{TSS}_{\mathrm{i}}\right)^{*} 100$

where, $\mathrm{TSS}_{\mathrm{i}}$ is the initial suspended solids concentration $\left(\mathrm{g} \mathrm{L}^{-1}\right.$ ) before the pretreatment and $\mathrm{TSS}_{\mathrm{f}}$ is the final suspended solids concentration after the pretreatment.

\section{Bacterial strains and culture conditions}

T. maritima DSM 3109 was obtained from the Deutsche Sammlung von Mikroorganismen und Zellkulturen (DSMZ). The culture medium of T. maritima contained FVW, natural seawater, $\mathrm{NH}_{4} \mathrm{Cl}\left(1 \mathrm{~g} \mathrm{~L}^{-1}\right)$, and cysteine $\mathrm{HCl}\left(0.3 \mathrm{~g} \mathrm{~L}^{-1}\right)$ as reported by Saidi et al. [19]. The $\mathrm{pH}$ was adjusted at 7.0 with $1 \mathrm{M}$ $\mathrm{NaOH}$ and distributed into $250 \mathrm{~mL}$ serum bottles with a working volume of $60 \mathrm{~mL}$. The serum bottles were made in anaerobic conditions by flushing with sterile nitrogen gas and were reduced with $\mathrm{Na}_{2} \mathrm{~S}\left(0.4 \mathrm{~g} \mathrm{~L}^{-1}\right)$. After inoculation with $\mathrm{T}$. maritima $(10 \% \mathrm{v} / \mathrm{v})$, the serum bottles were incubated at $80{ }^{\circ} \mathrm{C}$ without shaking. These precultures were used to inoculate the bioreactor.

\section{Stirred tank reactor and operating conditions}

Batch fermentations of T. maritima were performed in a STR of $2.5 \mathrm{~L}$ as described by Saidi et al. [19]. The STR with a working volume of $1.1 \mathrm{~L}$ was inoculated with a preculture of T. maritima $(10 \% \mathrm{v} / \mathrm{v})$. The mixture was kept anaerobic by sparging with continuous sterile nitrogen gas at a flow rate of $50 \mathrm{~mL} \mathrm{~min}^{-1}$. The bioreactor was stirred at $150 \mathrm{rpm}$ with an electric motor (IKA EUROSTAR 20 digital). It was heated $\left(80 \pm 0.5^{\circ} \mathrm{C}\right.$ ) by thermal recirculation of water in the double envelope jacket of the bioreactor using a heat bath. The outlet gas was condensed in a water cooler condenser $\left(7^{\circ} \mathrm{C}\right)$ to avoid the liquid loss in the STR. A probe (Mettler Toledo InPro 3253, Switzerland) was placed in the bioreactor to monitor $\mathrm{pH}$, temperature and redox potential. The adjustment of $\mathrm{pH}$ at $7.0 \pm 0.1$ was automatic by the addition of $1 \mathrm{M} \mathrm{NaOH}$. The measurements of carbon dioxide content in the STR outlet gas were done via a probe connected to a transmitter (Vaisala Series GMT221, Finland).

The culture medium of $\mathrm{T}$. maritima contained natural seawater, MFVW, AHFW, $\mathrm{NH}_{4} \mathrm{Cl}$ and cysteine $\mathrm{HCl}$. The details of the experimental conditions of the experiments performed in triplicate are presented in Table 1.

\section{Chemical and analytical analysis}

Total solids (TS), volatile solids (VS), total organic carbon (TOC), total kjeldahl nitrogen (TKN), chemical oxygen demand (COD) and $\mathrm{pH}$ of the substrates were determined according to standard methods [31]. Determination of carbohydrate concentrations was performed using the anthrone sulfuric acid method as described by Saidi et al. [19]. Cellulose and hemicelluloses concentrations were measured according to Sun et al. [32].

During fermentation, the residual sugars (glucose and fructose) and metabolic products (acetate and lactate) concentrations were analyzed by high performance liquid chromatography HPLC (Agilent 1200 series, USA) equipped with a quaternary pump coupled to a refractive index detector (RID) and an Aminex HPX-87H ion-exchange column $(300 \times 7.8 \mathrm{~mm}$, Bio-Rad). Liquid samples resulting from batch fermentations were centrifuged at $14000 \times g$ for $5 \mathrm{~min}$. The supernatants were filtered through a $0.45 \mu \mathrm{m}$ cellulose acetate Minisart syringe filter (Sartorius Stedim). Sulfuric acid $5 \mathrm{mmol} \mathrm{L}^{-1}$ was used as a mobile phase with a flow rate of $0.5 \mathrm{~mL} \mathrm{~min}^{-1}$. The HPLC was connected to a computer running ChemStation software.

Hydrogen measurements were performed at regular intervals of $30 \mathrm{~min}$ by a gas chromatograph (GC, Perichrom Company, France) which was connected to a computer running WINILAB III software. The GC was equipped with a thermal conductivity detector (TCD) and a concentric CTR1 column (Alltech, USA). The operating temperatures of the detector, the injector, and the oven were $100{ }^{\circ} \mathrm{C}, 100{ }^{\circ} \mathrm{C}$, and $40^{\circ} \mathrm{C}$, respectively. Argon was used as the carrier gas at a flow rate of $20 \mathrm{~mL} \mathrm{~min}{ }^{-1}$.

\section{Results and discussion}

\section{Physical and chemical characterization of substrates}

The average characteristics of the MFVW and AHFW used in this study and their standard errors are listed in Table 2. The VS content in MFVW and AHFW were $94.6 \%$ and $91 \%$,

\section{Table 1 - Experimental conditions for the STR batch fermentations.}

\begin{tabular}{|c|c|c|c|c|c|c|}
\hline Experiments & MFVW (mL) & AHFW (mL) & Seawater (mL) & Cysteine $\mathrm{HCl}$ & $\mathrm{NH}_{4} \mathrm{Cl}$ & $\mathrm{C} / \mathrm{N}$ \\
\hline E1 & 100 & 0 & 890 & + & + & 47 \\
\hline E2 & 100 & 50 & 840 & + & + & 32.4 \\
\hline E3 & 100 & 100 & 790 & + & + & 25.1 \\
\hline E4 & 100 & 250 & 640 & + & + & 15.7 \\
\hline E5 & 100 & 400 & 490 & + & + & 12 \\
\hline E6 & 100 & 50 & 840 & - & - & 32.4 \\
\hline E7 & 100 & 100 & 790 & - & - & 25.1 \\
\hline E8 & 100 & 250 & 640 & - & - & 15.7 \\
\hline E9 & 100 & 400 & 490 & - & - & 12 \\
\hline E10 & 200 & 400 & 390 & - & - & 17.8 \\
\hline E11 & 300 & 400 & 290 & - & - & 22 \\
\hline $\begin{array}{l}+: \text { Present. } \\
\text {-: Absent. }\end{array}$ & & & & & & \\
\hline
\end{tabular}


Table 2 - Physical and chemical characterization of MFVW and AHFW.

\begin{tabular}{|c|c|c|}
\hline Parameters & MFVW & AHFW \\
\hline Total solids (TS) (\% wb) & $10.1 \pm 0.1$ & $4.4 \pm 0.4$ \\
\hline Volatile solids (\%/TS) & $94.6 \pm 1.7$ & $91 \pm 1.2$ \\
\hline Total COD $\left(\mathrm{g} \mathrm{L}^{-1}\right)$ & $148 \pm 2.5$ & $50 \pm 1.3$ \\
\hline Particulate COD $\left(\mathrm{g} \mathrm{L}^{-1}\right)$ & $52 \pm 4.1$ & - \\
\hline Soluble COD $\left(\mathrm{g} \mathrm{L}^{-1}\right)$ & $96 \pm 4$ & - \\
\hline Total organic carbon $\left(\mathrm{g} \mathrm{L}^{-1}\right)$ & $103.6 \pm 4.5$ & $39 \pm 1.2$ \\
\hline Carbohydrates $\left(\mathrm{g} \mathrm{L}^{-1}\right)$ & $106 \pm 1.9$ & $13.5 \pm 0.3$ \\
\hline Total Kjeldahl Nitrogen (g.L $\mathrm{L}^{-1}$ ) & $2.2 \pm 0.04$ & $12 \pm 2.8$ \\
\hline Lipids (g/100g) & $2.5 \pm 1.5$ & $1.8 \pm 0.6$ \\
\hline Reducing sugars $\left(\mathrm{g} \mathrm{L}^{-1}\right)$ & $83.5 \pm 5.6$ & 0 \\
\hline $\mathrm{pH}$ & $4.07 \pm 0.09$ & $2 \pm 2.05$ \\
\hline Cellulose $\left(\mathrm{g} \mathrm{L}^{-1}\right)$ & $4.5 \pm 0.7$ & 0 \\
\hline Hemicellulose $\left(\mathrm{g} \mathrm{L}^{-1}\right)$ & $1.9 \pm 0.2$ & 0 \\
\hline Reducing sugars (HPLC) (g.L ${ }^{-1}$ ) & $84.1 \pm 0.3$ & 0 \\
\hline $\mathrm{C} / \mathrm{N}$ & 47 & 3.25 \\
\hline
\end{tabular}

respectively. The total organic carbon concentrations in MFVW and AHFW were $103.6 \mathrm{~g} \mathrm{~L}^{-1}$ and $15 \mathrm{~g} \mathrm{~L}^{-1}$, respectively. The high protein content of AHFW $\left(12 \mathrm{~g} \mathrm{~L}^{-1}\right)$ is the result of proteins solubilization during acid hydrolysis and the removal of insoluble solid matter by centrifugation [33]. Several studies reported that the protein content of fish protein hydrolysates is ranging between $60 \%$ and $90 \%$ of the total composition [33].

\section{Effect of increasing the amount of AHFW on $\mathrm{H}_{2}$ production}

The hydrogen production by T. maritima from MFVW with the supply of a gradually increased amount of AHFW in the minimum medium was evaluated either with $\left(E_{2}\right.$ to $\left.E_{5}\right)$ or without (E6 to E9) the addition of $\mathrm{NH}_{4} \mathrm{Cl}$ and cysteine $\mathrm{HCl}$ (Table 1). Results are presented in Fig. 1 and Table 3. Experiment $E_{1}$ was performed using MFVW as a substrate with the addition of $\mathrm{NH}_{4} \mathrm{Cl}$ and cysteine $\mathrm{HCl}$. After the addition of AHFW in the presence of $\mathrm{NH}_{4} \mathrm{Cl}$ and cysteine $\mathrm{HCl}$, the hydrogen production was improved. The cumulative $\mathrm{H}_{2}$ production increased from $109 \mathrm{mmol} \mathrm{L}^{-1}\left(E_{1}\right)$ to $176 \mathrm{mmol} \mathrm{L}^{-1}$ reaching $\mathrm{H}_{2}$ yield of $3.87 \mathrm{~mol} \mathrm{H}_{2} \mathrm{~mol}^{-1}$ hexose in experiment $\mathrm{E}_{5}$ where the $\mathrm{C} / \mathrm{N}$ ratio was 12 (Fig. 1, Table 3). However, the maximum $\mathrm{H}_{2}$ productivity increased approximately threefold times than that in $E_{1}$. These results confirm the positive effect of using the AHFW as co-substrate on $\mathrm{H}_{2}$ production by T.maritima, despite the appearance of a lag phase of approximately 2-3 hours (Fig. 2). In fact, T. maritima takes some time to adapt to its new substrate in the culture medium. In previous studies, yeast extract was considered the best organic nitrogen source for hydrogen production. It provides amino acids, peptides, nitrogen, carbohydrates, vitamins, mineral elements and other growth compounds necessary for the growth of microorganisms [34]. In this study, despite the absence of yeast extract in co-digestion assays, the maximum $\mathrm{H}_{2}$ productivity (24.6 mmol h $\mathrm{h}^{-1} \mathrm{~L}^{-1}$ ) was higher than that (7.3 $\left.\mathrm{mmol} \mathrm{h}^{-1} \mathrm{~L}^{-1}\right)$ achieved by Saidi et al. [19] in the presence of yeast extract $\left(1 \mathrm{~g} \mathrm{~L}^{-1}\right)$. In fact, fish protein hydrolysates were considered an important source of nitrogen (enzymes, proteins, and nucleic acids) for maintaining the growth of different microorganisms [35]. Moreover, AHFW are rich in peptides and free amino acids which are taken by the cell and directly used for protein synthesis or for their transformation into other nitrogenous cellular constituents [36].

The effect of using different $\mathrm{C} / \mathrm{N}$ ratios on co-digestion assays in the absence of $\mathrm{NH}_{4} \mathrm{Cl}$ and cysteine $\mathrm{HCl}$ was investigated $\left(E_{6}, E_{7}, E_{8}\right.$, and $\left.E_{9}\right)$ (Table 1). Increasing the amount of
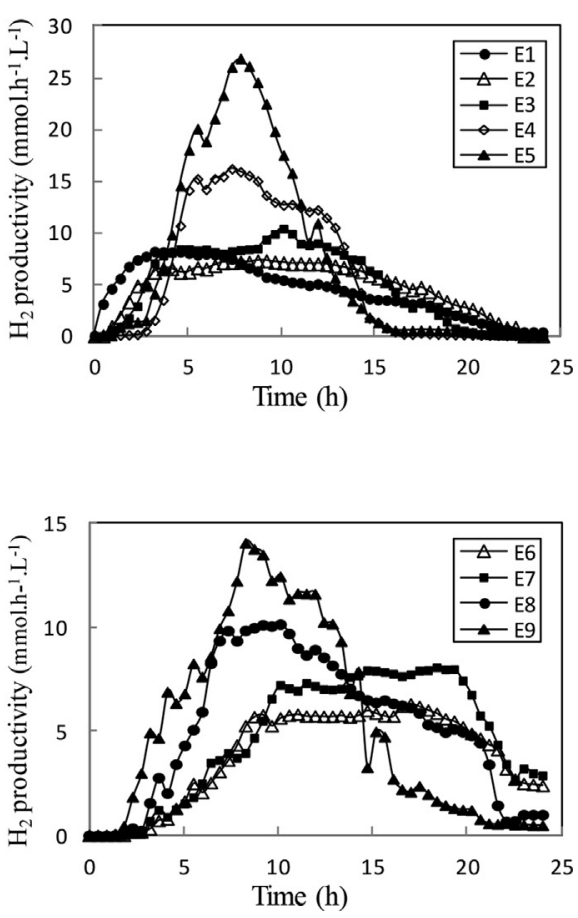

Fig. 1 - Cumulative $\mathrm{H}_{2}$ production and $\mathrm{H}_{2}$ productivity versus time in batch experiments with increasing amounts of AHFW with $\left(E_{1}, E_{2}, E_{3}, E_{4}\right.$ and $\left.E_{5}\right)$ or without $\left(E_{6}, E_{7}, E_{8}\right.$ and $\left.E_{9}\right)$ Cysteine $\mathrm{HCl}$ and $\mathrm{NH}_{4} \mathrm{Cl}$ addition. 


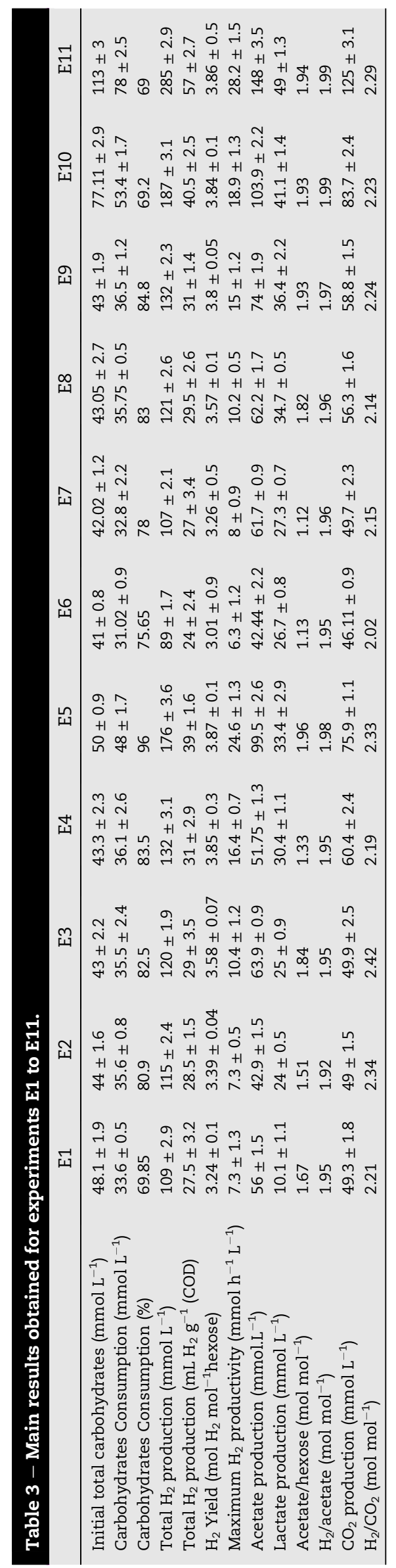

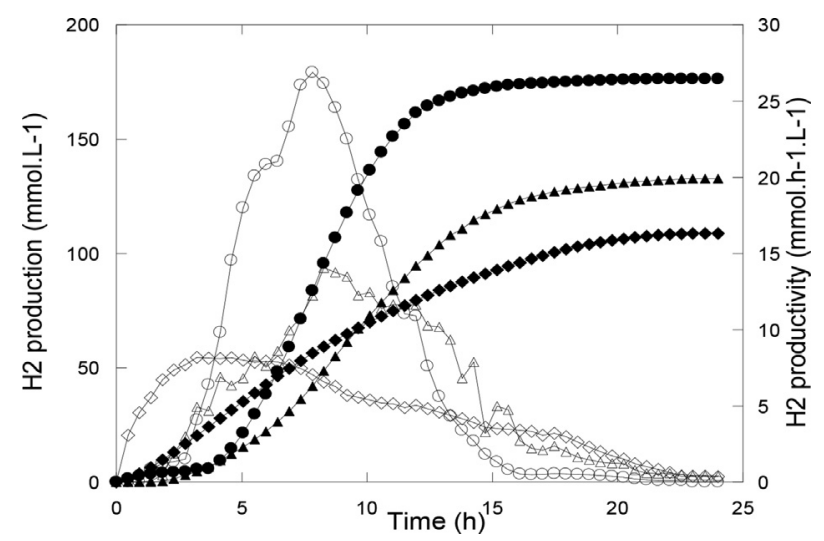

Fig. 2 - Cumulative $H_{2}$ production $\left(E_{1}: \diamond, E_{5}: \bullet, E_{9}: \nabla\right)$ and $\mathrm{H}_{2}$ productivity $\left(\mathrm{E}_{1}: \diamond, \mathrm{E}_{5}: \bigcirc, \mathrm{E}_{9}: \nabla\right)$ versus time.

AHFW to obtain a C/N ratio of $12\left(\mathrm{E}_{9}\right)$, has improved the $\mathrm{H}_{2}$ production from $109 \mathrm{mmol} \mathrm{L}^{-1}\left(E_{1}\right)$ to $132 \mathrm{mmol} \mathrm{L}^{-1}$, despite the absence of $\mathrm{NH}_{4} \mathrm{Cl}$ and cysteine $\mathrm{HCl}$ (Fig. 1, Table 3). Therefore, this enhancement could be attributed to the presence of AHFW that contain compounds able to provide nitrogen and sulfur indispensable for $T$. maritima growth as reported by some studies $[19,37]$. Indeed, the acid hydrolysis of fish wastes has broken complex proteins into small peptides and single amino acids which could be consumed by this halophilic bacterium. Moreover, many studies showed that aquatic organisms can use easily the low molecular weight peptides which can be absorbed rapidly than single amino acids and whole proteins [38,39]. In addition, Rinker and Kelly [37] reported that T. maritima did not significantly consume individual amino acids added to culture media. Sardina pilchardu is also characterized by the presence of sulfur amino acids (methionine, cysteine) and sulfur compound indispensable for $T$. maritima growth. These compounds are essential for protein, Fe-S clusters, and ferredoxin synthesis. Also, Prost et al. [40] showed that dimethyl sulfide which was considered one of the most important sulfur compounds is present in Sardina pilchardu (18.0\%). This component was obtained from amino acid degradation [40].

The comparison between experiments showed a similarity between $\mathrm{E}_{7}$ and $\mathrm{E}_{1}$ with $\mathrm{H}_{2}$ yield of $3.25 \mathrm{~mol} \mathrm{H}_{2} \mathrm{~mol}^{-1}$ hexose. This result showed that using $100 \mathrm{~mL}$ of AHFW could substitute compounds coming from $\mathrm{NH}_{4} \mathrm{Cl}\left(\mathrm{g} \mathrm{L}^{-1}\right)$ and cysteine $\mathrm{HCl}$ (0.3 $\left.\mathrm{g} \mathrm{L}^{-1}\right)$ with a preference to use organic compounds. In addition, many studies showed that the synthesis of amino acids for protein synthesis from organic nitrogen is rapid and required few energy compared to that performed from inorganic sources [34,36].

\section{Effect of using AHFW on metabolic pathway of T.maritima}

T. maritima is known to metabolize a broad range of sugars. It uses for glycolysis the Embden-Meyerhof (85\%) and the Entner-Doudouroff (15\%) pathway to produce $\mathrm{H}_{2}$, acetate, and $\mathrm{CO}_{2}$ as major by-products [15]. Frock et al. [14] reported that $\mathrm{H}_{2}$ production is associated with the conversion of all hexoses to acetate because there is no fleeing of electrons in other reactions. 
The evolution of cumulative $\mathrm{H}_{2}$ production and $\mathrm{H}_{2}$ productivity in experiments $E_{1}, E_{5}$ and $E_{9}$ versus time is presented in Fig. 2. Results showed a significant improvement in the production of $\mathrm{H}_{2}$ using co-digestion of MFVW and AHFW, suggesting a complementary effect between these two substrates. However, co-digestion assays in the absence of $\mathrm{NH}_{4} \mathrm{Cl}$ and cysteine $\mathrm{HCl}$ showed a lag phase of 2-3 h. In fact, the delay of $\mathrm{H}_{2}$ production was a result of these nutrients absence. The higher $\mathrm{H}_{2}$ productivity $\left(24.6 \mathrm{mmol} \mathrm{h}^{-1} \mathrm{~L}^{-1}\right)$ was obtained in $\mathrm{E} 5$ containing $\mathrm{NH}_{4} \mathrm{Cl}$ and cysteine $\mathrm{HCl}$ which indicate that despite the importance of using AHFW as a co-substrate, the supply of $\mathrm{NH}_{4} \mathrm{Cl}$ and cysteine $\mathrm{HCl}$ would further improve $\mathrm{T}$. maritima growth and $\mathrm{H}_{2}$ production kinetics. In addition, results indicate that cysteine $\mathrm{HCl}$ was used as reducing compound [41]. It reduces rapidly the redox potential (Eh) in the culture medium down to $-350 \mathrm{mV}$ due to the establishment of anaerobic conditions (data not shown). This condition could induce earlier the metabolic activity initiation of T. maritima. Ravot et al. [42] reported that the addition of sulfured compounds, such as dimethyl sulfide, methionine, cysteine, and thiosulfate, relieve the inhibition of $\mathrm{H}_{2}$ and enhance the cellular growth. Consequently, the small amount of sulfur will be given as a priority to protein synthesis rather than the Fe-S clusters formation of hydrogenases involved in the production of hydrogen [43].

The fermentative end products (acetate and lactate) and the cumulative $\mathrm{H}_{2}$ production in experiments $E_{1}, E_{5}$ and $E_{9}$ are presented in Table 3 and Fig. 3. The production of lactate was higher in the co-digestion experiments $\left(E_{5}\right.$ and $\left.E_{9}\right)$ than that achieved in $E_{1}$. The concentration of lactate in $E_{9}$ was $36.4 \mathrm{mmol} \mathrm{L}^{-1}$ which is approximately four-fold compared to $\mathrm{E}_{1}$. The production of hydrogen in $\mathrm{E}_{9}$ remained high $(3.8 \mathrm{~mol}$ $\mathrm{H}_{2} \mathrm{~mol}^{-1}$ hexose) (Table 3) despite high lactate production. Therefore, the presence of AHFW as co-substrate without $\mathrm{NH}_{4} \mathrm{Cl}$ and cysteine $\mathrm{HCl}$ addition induced T. maritima to shift its metabolism from hydrogen and acetate to lactate production via lactate dehydrogenase as described by Willquist and van Niel [44]. Moreover, many studies indicated that during fermentative $\mathrm{H}_{2}$ production by Thermotoga species, lactate production can vary from trace amounts to levels resembling that of acetate [14,15]. Schröder et al. [15] showed that lactate formation was detected in particular by T. maritima. Also, Verhaart et al. [45] confirmed that some hyperthermophiles were able to allow $\mathrm{H}_{2}$ yields close the thauer limit, suggesting

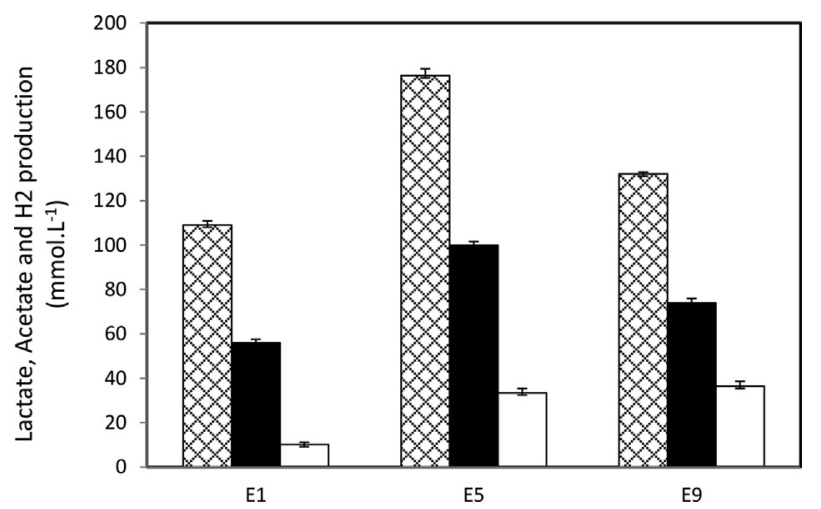

Fig. 3 - Comparative production of $\mathrm{H}_{2}(\otimes)$, Acetate $(\square)$ and Lactate $(\square)$ at $24 \mathrm{~h}$ between experiments $E_{1}, E_{5}$ and $E_{9}$. that, despite the more production of lactate and ethanol, nicotinamide adenine dinucleotide dehydrogenase (NADH) is used for proton reduction to form hydrogen.

The evolution of lactate production versus time is illustrated in Fig. 4. During the growth phase, the production of lactate started slowly and accelerated after the transition from the exponential growth phase to the stationary phase (Fig. 4). This production is correlated with the total consumption of carbohydrates by T. maritima and the reduced production of $\mathrm{H}_{2}$ and acetate.

In general, hydrogenases which constitute a family of metalloenzymes, reduce protons to hydrogen by lowpotential electrons in order to dispose of excess reductants that are generated during fermentation [46]. Consequently, hydrogen is a waste product that its formation serves as a physiological mechanism to protect the bacterial cells [46]. Dipasquale et al. [47] explained the formation of lactate as a manner to improve the disposal of the surplus by reducing power. However, the production of hydrogen and lactate compete for the utilization of reducing power. They reported that the conversion of $1 \mathrm{~mol}$ of pyruvate to lactate by lactate dehydrogenase requires oxidation of $1 \mathrm{~mol}$ of nicotinamide adenine dinucleotide dehydrogenase (NADH), as the production of $2 \mathrm{~mol}$ of hydrogen. Lakhal et al. [41] observed that the metabolism of T. maritima shifts towards lactate production under oxidative conditions. Furthermore, the presence of substrates difficult to hydrolyze could be responsible for the distribution of catabolic and anabolic fluxes leading to different metabolite levels that modulate lactate dehydrogenase activity [44]. In addition, the production of lactate depends on culture conditions such as high $\mathrm{H}_{2}$ partial pressure, the transition to stationary phase and the shift of metabolic of pyruvate towards lactate production via lactate dehydrogenase [44].

Recently, some studies reported that the use of an atmosphere enriched in carbon dioxide stimulated the synthesis of lactate by T. neapolitana, which has similar characteristics to $\mathrm{T}$. maritima. This process was named capnophilic lactic fermentation (fermentative $\mathrm{CO}_{2}$-dependent) where lactate formation was the result of the association of exogenous $\mathrm{CO}_{2}$ with acetyl-CoA $[9,47,48]$. Dipasquale et al. [47] showed that the high production of lactate (up to $0.6 \mathrm{~mol} \mathrm{~mol}^{-1}$ glucose)

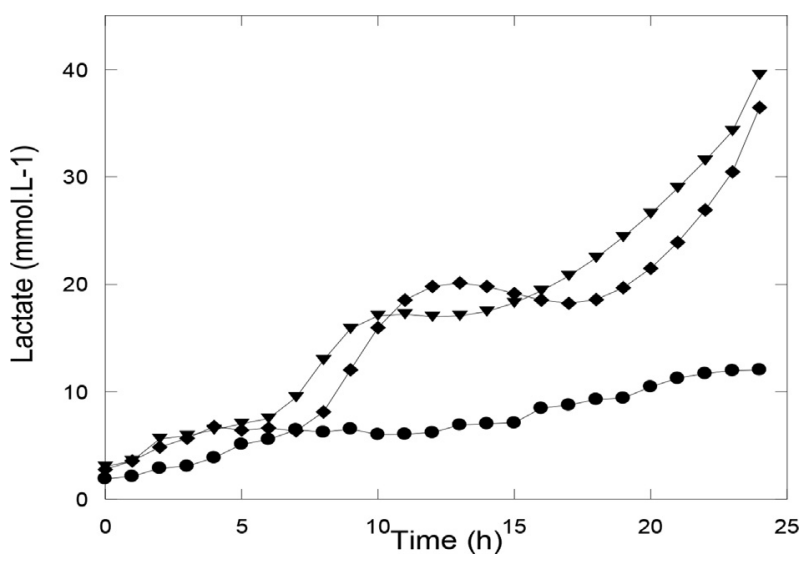

Fig. 4 - Lactate production versus time for experiment $E_{1}$ : $\odot, E_{5}: \diamond$ and $E_{9}: \nabla$. 

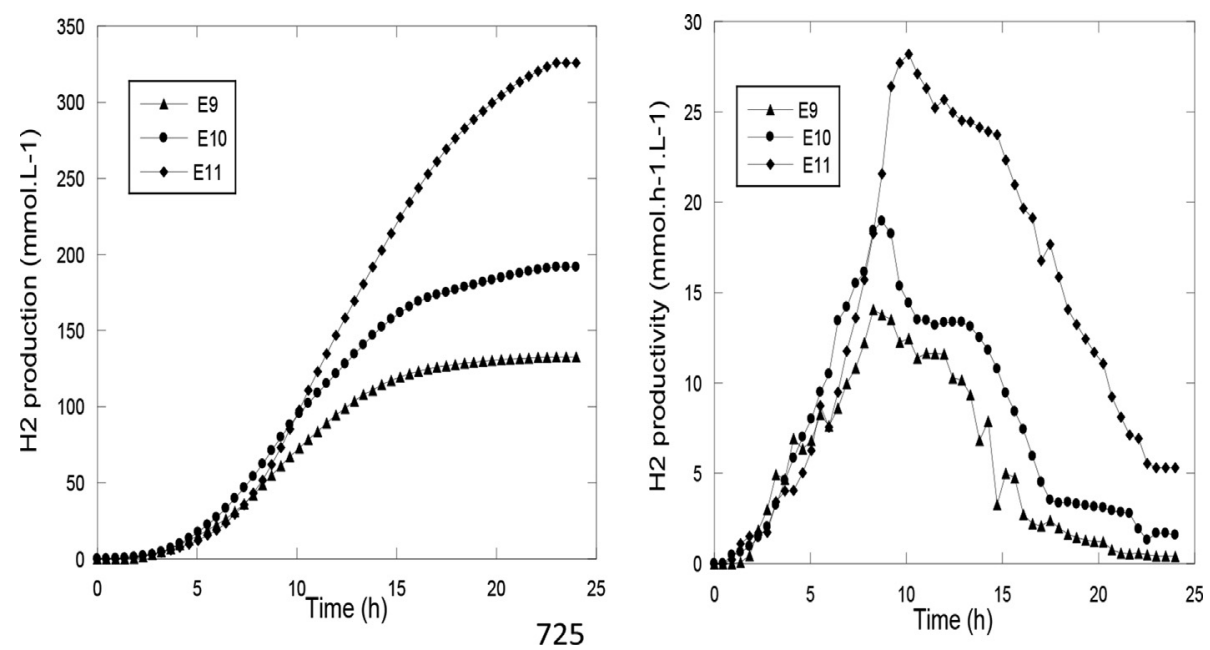

Fig. 5 - Cumulative $\mathrm{H}_{2}$ production and $\mathrm{H}_{2}$ productivity in batch experiments at different proportions of MFVW in the absence of Cysteine $\mathrm{HCl}$ and $\mathrm{NH}_{4} \mathrm{Cl}$.

does not affect the production of $\mathrm{H}_{2}$ which was around $3.6 \mathrm{~mol} \mathrm{~mol}{ }^{-1}$ glucose. These results were confirmed by d'Ippolito et al. [48] those observed the shift of the metabolism of $\mathrm{T}$. neapolitana from acetate to lactate formation during the capnophilic lactic fermentation. The production of $\mathrm{H}_{2}$ remains high through an additional consumption of reducing equivalents deriving from other cellular processes [48].

\section{Effect of increasing the amount of MFVW on $\mathrm{H}_{2}$ production}

Experiments $E_{9}, E_{10}$ and $E_{11}$ were performed with the same volume of AHFW ( $400 \mathrm{~mL}$ ) and different proportions of MFVW in the absence of cysteine $\mathrm{HCl}$ and $\mathrm{NH}_{4} \mathrm{Cl}$ (Table 1). The corresponding cumulative $\mathrm{H}_{2}$ production and $\mathrm{H}_{2}$ productivity are presented in Fig. 5 and Table 3. The increase of the carbohydrates concentration in $\mathrm{E}_{11}\left(123 \mathrm{mmol} \mathrm{L}^{-1}\right)$ to reach a $\mathrm{C} / \mathrm{N}$ ratio of 22, allowed a cumulative $\mathrm{H}_{2}$ production 2.5 times higher than that obtained in $\mathrm{E}_{9}(\mathrm{C} / \mathrm{N}$ ratio $=12)($ Table 3$)$. Consequently, the highest $\mathrm{H}_{2}$ productivity $\left(28 \mathrm{mmol} \mathrm{h}^{-1} \mathrm{~L}^{-1}\right)$ and $\mathrm{H}_{2}$ yield ( $3.86 \mathrm{~mol} \mathrm{H}_{2} \mathrm{~mol}^{-1}$ hexose) achieved at $\mathrm{C} / \mathrm{N}$ ratio of 22 were associated with a significant consumption of carbohydrates (69\%) within $24 \mathrm{~h}$ of fermentation (Table 3). These results suggest that the improvement of hydrogen production by $\mathrm{T}$. maritima could be a function of the $\mathrm{C} / \mathrm{N}$ ratio and the proportions of MFVW and AHFW in the mixture. In addition, the high production of hydrogen is due to the high activity of T. maritima considered one of the most important $\mathrm{H}_{2}$-producing bacterium. In fact, this bacterium produces a wide range of thermostable hydrolytic enzymes (cellulases, invertase, and xylanases) necessary for hydrolyzing a wide variety of simple and complex carbohydrates [28]. However, Nguyen et al. [13] observed that the concentration of glucose over $15 \mathrm{~g} \mathrm{~L}^{-1}$ has a negative effect on $\mathrm{H}_{2}$ production and cell growth of T. maritima and T. neapolitana in batch cultures. Therefore, the use of fruit and vegetable wastes is better than glucose because they play an important role in the fermentation process. They provide mineral elements, amino acids and vitamins essential for the metabolic activity of T. maritima [19]. Moreover, this bacterium is able to use the glucose-based complex carbohydrates due to its genome which code for a large number of glycoside hydroxylases. These enzymes hydrolyze the glycosidic bond between carbohydrates or between a carbohydrate and a non-carbohydrate fraction [12].

\section{$\mathrm{H}_{2}$ potential of T. maritima and energy recovery efficiency}

Table 4 summarizes the performance of $\mathrm{H}_{2}$ production by some Thermotoga strains from various substrates reported in

Table 4 - The comparison of batch fermentative hydrogen production performances by some Thermotoga. sp from various substrates reported in the literature.

\begin{tabular}{|c|c|c|c|c|c|c|}
\hline Strain & Carbon source & $\begin{array}{l}\text { Substrate } \\
\qquad\left(\mathrm{g} \mathrm{L}^{-1}\right)\end{array}$ & $\begin{array}{l}\mathrm{H}_{2} \text { yields (mol } \mathrm{H}_{2} \\
\text { mol }^{-1} \text { substrate) }\end{array}$ & $\begin{array}{l}\text { Maximum } \mathrm{H}_{2} \text { productivity } \\
\left(\mathrm{mmol} \mathrm{h}^{-1} \mathrm{~L}^{-1}\right)\end{array}$ & By-products & References \\
\hline T.maritima & MFVW-AHFW & 20 & 3.86 & 28.2 & Acetate, lactate, $\mathrm{CO}_{2}$ & This study \\
\hline T.maritima & Glucose & 7.5 & 1.7 & 8.2 & - & [13] \\
\hline T.maritima & Arabinose & 5 & 3.2 & 0.6 & Acetate, lactate, $\mathrm{CO}_{2}$ & [49] \\
\hline T.maritima & Xylose & 5 & 2.7 & 0.4 & Acetate, lactate, $\mathrm{CO}_{2}$ & [49] \\
\hline T.maritima & MFVW & 8.1 & 3.89 & 12.4 & Acetate, lactate, $\mathrm{CO}_{2}$ & [19] \\
\hline T.neapolitana & Potato steam peels & 10 & 3.8 & 12.5 & Acetate, lactate, $\mathrm{CO}_{2}$ & {$[50]$} \\
\hline T.neapolitana & Miscanthus hydrolysate & 10 & 3.2 & 13.1 & Acetate, lactate, $\mathrm{CO}_{2}$ & [51] \\
\hline T.neapolitana & Carrot pulp & 10 & 2.8 & 12.5 & Acetate, lactate, $\mathrm{CO}_{2}$ & {$[52]$} \\
\hline T.neapolitana & Molasses & 20 & 2.64 & 1.7 & Acetate, lactate, $\mathrm{CO}_{2}$ & [28] \\
\hline T.neapolitana & Cheese whey & 12.5 & 2.4 & 0.94 & Acetate, lactate, $\mathrm{CO}_{2}$ & [28] \\
\hline
\end{tabular}


the literature. In this study, the maximum $\mathrm{H}_{2}$ productivity (28.2 $\mathrm{mmol} \mathrm{h}^{-1} \mathrm{~L}^{-1}$ ), obtained at $\mathrm{C} / \mathrm{N}$ ratio of 22 , is high when compared to the results of other studies. deVrije et al. [51] and Saidi et al. [19] used miscanthus hydrolysate and MFVW as substrates to obtain a maximum $\mathrm{H}_{2}$ productivity of $13.1 \mathrm{mmol} \mathrm{h}^{-1} \mathrm{~L}^{-1}$ and $12.4 \mathrm{mmol} \mathrm{h}^{-1} \mathrm{~L}^{-1}$, respectively. The maximum $\mathrm{H}_{2}$ productivity of $T$. Neapolitana reached by Cappelletti et al. [28] on molasses and cheese whey were 1.7 and $0.94 \mathrm{mmol} \mathrm{h}^{-1} \mathrm{~L}^{-1}$, respectively.

The energy recovery was calculated based on the hydrogen yield and the energy value of hydrogen which was reported to be $12.71 \mathrm{~kJ} \mathrm{~L}^{-1}$ [53]. In the optimal condition $\left(\mathrm{E}_{11}\right)$, the cumulative hydrogen yield was calculated as $89 \mathrm{~L} \mathrm{H}_{2} \mathrm{~kg}^{-1} \mathrm{VS}$. This yield compares well with the energy content of other lignocellulosic feedstocks as reported by Abreu et al. [54]. The use of lignocellulosic garden wastes by individual T. maritima and the co-culture of $\mathrm{T}$. maritima and $\mathrm{C}$. saccharolyticus, allowed a yield of 45.1 and $75.1 \mathrm{LH}_{2} \mathrm{~kg}^{-1} \mathrm{VS}$, respectively [54]. Moreover, the $\mathrm{H}_{2}$ yield obtained from food wastes mixtures varied between 25 and $85 \mathrm{LH}_{2} \mathrm{~kg}^{-1}$ VS as shown by Alibardi and Cossu [55].

Consequently, the achieved energy recovery was $12.0310^{3}$ MJ ton ${ }^{-1}$ wastes. Further studies on hydrogen production from organic wastes (Fish, fruit and vegetable wastes) should be considered at a pilot scale to include cost assessment investigation.

\section{Conclusion}

In this study, the feasibility of biohydrogen production by $T$. maritima from hyperthermophilic anaerobic co-digestion of MFVW and AHFW in seawater was investigated. The highest cumulative $\mathrm{H}_{2}$ production of $285 \mathrm{mmol} \mathrm{L}^{-1}$, leading to $\mathrm{H}_{2}$ yield of $3.86 \mathrm{~mol} \mathrm{H}_{2} \mathrm{~mol}^{-1}$ hexose, was obtained in the experiment that was performed at $\mathrm{C} / \mathrm{N}$ ratio of 22 . The maximum $\mathrm{H}_{2}$ productivity was $28 \mathrm{mmol} \mathrm{h}^{-1} \mathrm{~L}^{-1}$. Therefore, the rich composition of MFVW and AHFW associated with the elements provided by seawater, allow an appropriate carbon to nitrogen ratio which enhanced the production of $\mathrm{H}_{2}$. In fact, AHFW are an important source of nitrogen and sulfur. Consequently, using marine codigestion process could bean interesting cost-effective alternative to produce biohydrogen without chemical compounds addition. Future development studies would be occurring at a pilot scale to obtain further data on the economic, technical and environmental implications of this promising process for biotechnological applications.

\section{Acknowledgements}

Authors gratefully acknowledge the Tunisian Ministry of Higher Education and Scientific Research and the French Research Institute for Development (IRD) for their technical and financial support.

\section{R E F E R E N C E S}

[1] Shafiee S, Topal E. When will fossil fuel reserves be diminished? Energy Pol 2009;37:181-9. https://doi.org/ 10.1016/j.enpol.2008.08.016.
[2] Ljunggren M, Zacchi G. Techno-economic evaluation of a two-step biological process for hydrogen production. Biotechnol Prog 2010;26:496-504. https://doi.org/10.1002/ btpr.336.

[3] Chandrasekhar K, Lee Y-J, Lee D-W. Biohydrogen production: strategies to improve process efficiency through microbial routes. Int J Mol Sci 2015;16:8266-93. https://doi.org/10.3390/ ijms16048266.

[4] Argun H, Gokfiliz P, Karapinar I. Biohydrogen production potential of different biomass sources. In: Biohydrogen Prod Sustain Curr Technol Future Perspect. New Delhi: Springer; 2017. p. 11-48. https://doi.org/10.1007/978-81-322-3577-4_2.

[5] Pathak VV, Ahmad S, Pandey A, Tyagi VV, Buddhi D, Kothari R. Deployment of fermentative biohydrogen production for sustainable economy in indian scenario: practical and policy barriers with recent progresses. Curr Sustain Energy Rep 2016;3:101-7. https://doi.org/10.1007/ s40518-016-0052-2.

[6] Hallenbeck PC, Ghosh D, Skonieczny MT, Yargeau V. Microbiological and engineering aspects of biohydrogen production. Indian J Microbiol 2009;49:48-59. https://doi.org/ 10.1007/s12088-009-0010-4.

[7] Guo XM, Trably E, Latrille E, Carrère H, Steyer J-P. Hydrogen production from agricultural waste by dark fermentation: a review. Int J Hydrogen Energy 2010;35:10660-73. https:// doi.org/10.1016/j.ijhydene.2010.03.008.

[8] Mohan SV. Waste to renewable energy: a sustainable and green approach towards production of biohydrogen by acidogenic fermentation. In: Singh OV, Harvey SP, editors. Sustain. Biotechnol. Sources Renew. Energy. Dordrecht: Springer Netherlands; 2010. p. 129-64. https://doi.org/ 10.1007/978-90-481-3295-9_7.

[9] Pradhan N, Dipasquale L, d'Ippolito G, Panico A, Lens PNL, Esposito G, et al. Hydrogen production by the thermophilic bacterium Thermotoga neapolitana. Int J Mol Sci 2015;16:12578-600. https://doi.org/10.3390/ijms160612578.

[10] Cardoso V, Romão BB, Silva FT, Santos JG, Batista FR, Ferreira JS. Hydrogen production by dark fermentation. Chem Eng Trans 2014;38:481-6.

[11] Cappelletti M, Zannoni D, Postec A, Ollivier B. Members of the order Thermotogales: from microbiology to hydrogen production. In: Microb BioEnergy Hydrogen Prod. Dordrecht: Springer; 2014. p. 197-224. https://doi.org/10.1007/978-94017-8554-9_9.

[12] Chhabra SR, Shockley KR, Conners SB, Scott KL, Wolfinger RD, Kelly RM. Carbohydrate-induced differential gene expression patterns in the hyperthermophilic bacterium Thermotoga maritima. J Biol Chem 2003;278:7540-52. https://doi.org/10.1074/jbc.M211748200.

[13] Nguyen TAD, Pyo Kim J, Sun Kim M, Kwan Oh Y, Sim SJ. Optimization of hydrogen production by hyperthermophilic eubacteria, Thermotoga maritima and Thermotoga neapolitana in batch fermentation. Int J Hydrogen Energy 2008;33:1483-8. https://doi.org/10.1016/j.ijhydene.2007.09.033.

[14] Frock AD, Notey JS, Kelly RM. The genus Thermotoga: recent developments. Environ Technol 2010;31:1169-81. https:// doi.org/10.1080/09593330.2010.484076.

[15] Schröder C, Selig M, Schönheit P. Glucose fermentation to acetate, $\mathrm{CO} 2$ and $\mathrm{H} 2$ in the anaerobic hyperthermophile ceubacterium Thermotoga maritima: involvement of the Embden-Meyerhof pathway. Arch Microbiol 1994;161:460-70. https://doi.org/10.1007/BF00307766.

[16] Zaky AS, Tucker GA, Daw ZY, Du C. Marine yeast isolation and industrial application. FEMS Yeast Res 2014;14:813-25. https://doi.org/10.1111/1567-1364.12158.

[17] Wu B, Tseng CK, Xiang W. Large-scale cultivation of spirulina in seawater based culture medium. Bot Mar 2009;36:99-102. https://doi.org/10.1515/botm.1993.36.2.99. 
[18] Domínguez de María P. On the use of seawater as reaction media for large-scale Applications in biorefineries. ChemCatChem 2013;5:1643-8. https://doi.org/10.1002/ cctc. 201200877.

[19] Saidi R, Liebgott PP, Gannoun H, Ben Gaida L, Miladi B, Hamdi $\mathrm{M}$, et al. Biohydrogen production from hyperthermophilic anaerobic digestion of fruit and vegetable wastes in seawater: simplification of the culture medium of Thermotoga maritima. Waste Manag 2018;71:474-84. https:// doi.org/10.1016/j.wasman.2017.09.042.

[20] De Gioannis G, Muntoni A, Polettini A, Pomi R. A review of dark fermentative hydrogen production from biodegradable municipal waste fractions. Waste Manag 2013;33:1345-61. https://doi.org/10.1016/j.wasman.2013.02.019.

[21] Bouallagui H, Lahdheb H, Ben Romdan E, Rachdi B, Hamdi M. Improvement of fruit and vegetable waste anaerobic digestion performance and stability with co-substrates addition. J Environ Manag 2009;90:1844-9. https://doi.org/ 10.1016/j.jenvman.2008.12.002.

[22] Gu YS, Yoon HS, Park DC, Ji CI, Cho TY, Kim MC, et al. Effects of muscle types and cooling on discoloration of canned skipjack. Fish Sci 2002;67:1145-50. https://doi.org/10.1046/ j.1444-2906.2001.00372.x.

[23] Nnali KE, Oke AO. The utilization of fish and fish farm wastes in biogas production: "a review". Adv Agric Sci Eng Res 2013;3:657-67.

[24] Kim D-H, Kim S-H, Kim H-W, Kim M-S, Shin H-S. Sewage sludge addition to food waste synergistically enhances hydrogen fermentation performance. Bioresour Technol 2011;102:8501-6. https://doi.org/10.1016/j.biortech.2011. 04.089.

[25] Tenca A, Schievano A, Perazzolo F, Adani F, Oberti R. Biohydrogen from thermophilic co-fermentation of swine manure with fruit and vegetable waste: maximizing stable production without $\mathrm{pH}$ control. Bioresour Technol 2011;102:8582-8. https://doi.org/10.1016/j.biortech.2011. 03.102.

[26] Gomez-Romero J, Gonzalez-Garcia A, Chairez I, Torres L, García-Peña EI. Selective adaptation of an anaerobic microbial community: biohydrogen production by codigestion of cheese whey and vegetables fruit waste. Int J Hydrogen Energy 2014;39:12541-50. https://doi.org/10.1016/ j.ijhydene.2014.06.050.

[27] Alqaralleh RM, Kennedy K, Delatolla R, Sartaj M. Thermophilic and hyper-thermophilic co-digestion of waste activated sludge and fat, oil and grease: evaluating and modeling methane production. J Environ Manag 2016;183:551-61. https://doi.org/10.1016/j.jenvman.2016. 09.003.

[28] Cappelletti M, Bucchi G, Mendes JDS, Alberini A, Fedi S, Bertin L, et al. Biohydrogen production from glucose, molasses and cheese whey by suspended and attached cells of four hyperthermophilic Thermotoga strains. J Chem Technol Biotechnol 2012;87:1291-301. https://doi.org/ 10.1002/jctb.3782.

[29] Mackie IM. The effects of freezing on flesh proteins. Food Rev Int 1993;9:575-610. https://doi.org/10.1080/875591293095 40979.

[30] Gao M-T, Hirata M, Toorisaka E, Hano T. Acid-hydrolysis of fish wastes for lactic acid fermentation. Bioresour Technol 2006;97:2414-20. https://doi.org/10.1016/j.biortech.2005.10. 002.

[31] APHA. Standard methods for the examination of water and wastewater. 21st ed. Washington, D. C.: American Public Health Association, American Water WorksAssociation, Water Environment Federation; 2005.

[32] Sun XF, Sun RC, Tomkinson J, Baird MS. Preparation of sugarcane bagasse hemicellulosic succinates using NBS as a catalyst. Carbohydr Polym 2003;53:483-95. https://doi.org/ 10.1016/S0144-8617(03)00150-4.

[33] Chalamaiah M, Dinesh kumar B, Hemalatha R, Jyothirmayi T. Fish protein hydrolysates: proximate composition, amino acid composition, antioxidant activities and applications: a review. Food Chem 2012;135:3020-38. https://doi.org/ 10.1016/j.foodchem.2012.06.100.

[34] Kalil MS, Alshiyab HS, Yusoff WMW. Effect of nitrogen source and carbon to nitrogen ratio on hydrogen production using C. acetobutylicum. Am J Biochem Biotechnol 2008;4:393-401. https://doi.org/10.3844/ajbbsp.2008.393.401.

[35] Ghimire A, Frunzo L, Pirozzi F, Trably E, Escudie R, Lens PNL, et al. A review on dark fermentative biohydrogen production from organic biomass: process parameters and use of byproducts. Appl Energy 2015;144:73-95. https://doi.org/ 10.1016/j.apenergy.2015.01.045.

[36] Ferchichi M, Crabbe E, Hintz W, Gil G-H, Almadidy A. Influence of culture parameters on biological hydrogen production by Clostridium saccharoperbutylacetonicum ATCC 27021. World J Microbiol Biotechnol 2005;21:855. https:// doi.org/10.1007/s11274-004-5972-0.

[37] Rinker KD, Kelly RM. Effect of carbon and nitrogen sources on growth dynamics and exopolysaccharide production for the hyperthermophilic archaeon Thermococcus litoralis and bacterium Thermotoga maritima. Biotechnol Bioeng 2000;69:537-47.

[38] Ziegler F, Ollivier JM, Cynober L, Masini JP, Coudray-Lucas C, Levy E, et al. Efficiency of enteral nitrogen support in surgical patients: small peptides v non-degraded proteins. Gut 1990;31:1277-83.

[39] Venturin A, GonçAlves AFN, Oliveira NS, Skoronski E, Pessatti ML, Fabregat TEHP. Soluble fraction of sardine protein hydrolysates in the feeding of the South American catfish. Bol Inst Pesca 2016;42:878-88. https://doi.org/ 10.20950/1678-2305.2016v42n4p878.

[40] Prost C, Hallier A, Cardinal M, Serot T, Courcoux P. Effect of storage time on raw sardine (Sardina pilchardus) flavor and aroma quality. J Food Sci 2004;69:S198-204. https://doi.org/ 10.1111/j.1365-2621.2004.tb10732.x.

[41] Lakhal R, Auria R, Davidson S, Ollivier B, Dolla A, Hamdi M, et al. Effect of oxygen and redox potential on glucose fermentation in Thermotoga maritima under controlled physicochemical conditions. Int J Microbiol 2010. https:// doi.org/10.1155/2010/896510.

[42] Ravot G, Ollivier B, Magot M, Patel B, Crolet J, Fardeau M, et al. Thiosulfate reduction, an important physiological feature shared by members of the order thermotogales. Appl Environ Microbiol 1995;61:2053-5.

[43] Ainala SK, Seol E, Kim JR, Park S. Effect of culture medium on fermentative and $\mathrm{CO}$-dependent $\mathrm{H} 2$ production activity in CitrobacteramalonaticusY19. Int J Hydrogen Energy 2016;41: 6734-42. https://doi.org/10.1016/j.ijhydene.2016.03.088.

[44] Willquist $\mathrm{K}$, van Niel EWJ. Lactate formation in Caldicellulosiruptor saccharolyticus is regulated by the energy carriers pyrophosphate and ATP. Metab Eng 2010;12:282-90. https://doi.org/10.1016/j.ymben.2010.01.001.

[45] Verhaart MRA, Bielen AAM, Oost J van der, Stams AJM, Kengen SWM. Hydrogen production by hyperthermophilic and extremely thermophilic bacteria and archaea: mechanisms for reductant disposal. Environ Technol 2010;31:993-1003. https://doi.org/10.1080/ 09593331003710244.

[46] Vignais PM, Billoud B. Occurrence, classification, and biological function of hydrogenases: an overview. Chem Rev 2007;107:4206-72. https://doi.org/10.1021/cr050196r.

[47] Dipasquale L, d'Ippolito G, Fontana A. Capnophilic lactic fermentation and hydrogen synthesis by Thermotoga neapolitana: an unexpected deviation from the dark 
fermentation model. Int J Hydrogen Energy 2014;39:4857-62. https://doi.org/10.1016/j.ijhydene.2013.12.183.

[48] d'Ippolito G, Dipasquale L, Fontana A. Recycling of carbon dioxide and acetate as lactic acid by the hydrogen-producing bacterium Thermotoga neapolitana. ChemSusChem 2014;7:2678-83. https://doi.org/10.1002/cssc.201402155.

[49] Eriksen NT, Riis ML, Holm NK, Iversen N. H(2) synthesis from pentoses and biomass in Thermotoga spp. Biotechnol Lett 2011;33:293-300. https://doi.org/10.1007/s10529-010-0439-x.

[50] Mars AE, Veuskens T, Budde MAW, Doeveren PFNM van, Lips SJ, Bakker RR, et al. Biohydrogen production from untreated and hydrolyzed potato steam peels by the extreme thermophiles Caldicellulosiruptor saccharolyticus and Thermotoga neapolitana. Int J Hydrogen Energy 2010;15:7730-7. https://doi.org/10.1016/j.ijhydene.2010. 05.063.

[51] de Vrije T, Bakker RR, Budde MA, Lai MH, Mars AE, Claassen PA. Efficient hydrogen production from the lignocellulosic energy crop Miscanthus by the extreme thermophilic bacteria Caldicellulosiruptor saccharolyticus and Thermotoga neapolitana. Biotechnol Biofuels 2009;2:12. https:// doi.org/10.1186/1754-6834-2-12.
[52] de Vrije T, Budde MAW, Lips SJ, Bakker RR, Mars AE, Claassen PAM. Hydrogen production from carrot pulp by the extreme thermophiles Caldicellulosiruptor saccharolyticus and Thermotoga neapolitana. Int J Hydrogen Energy 2010;35:13206-13. https://doi.org/10.1016/j.ijhydene.2010.09. 014.

[53] Fu S-F, Xu X-H, Dai M, Yuan X-Z, Guo R-B. Hydrogen and methane production from vinasse using two-stage anaerobic digestion. Process Saf Environ Protect 2017;107:81-6. https:// doi.org/10.1016/j.psep.2017.01.024.

[54] Abreu AA, Tavares F, Alves MM, Pereira MA. Boosting dark fermentation with co-cultures of extreme thermophiles for biohythane production from garden waste. Bioresour Technol 2016;219:132-8. https://doi.org/10.1016/j.biortech. 2016.07.096.

[55] Alibardi L, Cossu R. Composition variability of the organic fraction of municipal solid waste and effects on hydrogen and methane production potentials. Waste Manag 2015;36:147-55. https://doi.org/10.1016/ j.wasman.2014.11.019. 